\title{
The public, the private, and the business-societal: A threefold approach to business responsibility for human rights
}

Janne Mende

\section{Introduction}

In 2018, large companies such as Danone and BlackRock chief executive officer Larry Fink addressed the social and moral responsibilities of companies that go beyond mere shareholder-oriented profiteering. ${ }^{1}$ In the same year, Rana Plaza victims among others were still struggling for compensation. ${ }^{2}$ The Bangladeshi factory building collapsed in 2013 and caused more than 1000 deaths; more than 2000 workers were injured.

Overall, the role of business for the violation, but also for the protection of human rights has become a pivotal research agenda across the disciplines. Since the 1990s, debates increasingly focus on the question of whether, and if so to what extent, companies as private actors can be held responsible for human rights. This question of challenges the international human rights system that holds states as public actors responsible for the respect, protection, and fulfilment of human rights.

Against this background, this chapter argues that the conceptual frame of public and private does not suffice to capture business roles for human rights in times of global governance and globalisation. Instead, it suggests a threefold approach to the public, the private, and the business-societal. ${ }^{3}$ The latter denotes a third role of business companies that is situated between and simultaneously beyond the public and the private. The public, the private, and 
the business-societal build an intermediated three-pole constellation in which each pole constitutes and affects the other. In a subsequent step, this threefold approach provides the foundation for a business-societal form of responsibility as a new research agenda for human rights. Such a hybrid business responsibility for human rights can escape the impasse between purely public and merely private forms of responsibility for human rights.

The chapter starts by tracing the development of global governance and its effects on human rights that fuel the question of business responsibility for human rights in the first place. It then introduces two main controversies that shape the discussion of the business and human rights agenda. These are, first, whether the human rights system should provide direct or indirect measures to deal with business companies; and, second, whether business companies should assume non-binding or binding responsibilities for human rights. Both controversies are closely linked to the question as to where to situate companies in the constellation between public and private. On this basis, the chapter suggests a three-pole constellation between the public, the private, and the business-societal. It shows how the development of societal roles of business companies yields effects on all three poles of the constellation, and on human rights at its centre. The chapter concludes that the development of societal forms of business responsibility for human rights represent a much-needed research agenda.

\section{Global governance and human rights}

Global governance and its challenge of the state-centred human rights regime fuel the role of business as societal actors. Globalisation, global governance, and economic restructuring have changed the character of international relations, entangling not only major shifts of agency, regulation, power, and authority, but also of their very conceptual meaning. One of the most pervasive aspects of global governance is the supplementation of states by non-state actors (Graz and Nölke 2008; Jönsson and Tallberg 2010; Schuppert 2006; Take 2009). Disagreements about whether global governance is taking on the form of governance by, with, or without (multiple) governments notwithstanding (Brühl and Rittberger 2001, 5; Rosenau and Czempiel 1992), today perspectives prevail that acknowledge the role of both state and non-state actors in governance, and their mutual influence (Sassen 2006). While the term non-state actor covers a broad variety of actors, business companies are the most important non-state actors in global governance. 
Business companies are not simply gaining agency, but transnational agency, yielding effects within and beyond state borders (cf. Deva and Bilchitz 2013; Fuchs 2005; Brysk 2002; Muchlinski 2001). Transnational linkages not only pertain to transnational companies, i.e. companies with "the power to coordinate and control operations in more than one country" (Dicken 2011, 110) and that account for around 80 per cent of global trade (UNCTAD 2015). They also include small and medium-sized companies that are involved in global supply chains, production networks, and capital markets.

Transnational business agency challenges the human rights regime. First, it is difficult to identify a responsible actor for a human rights violation, especially when it comes to production and supply chains with short-term and flexible relations (Barrientos 2007). Second, it is difficult to tie an actor or an incidence to a state jurisdiction that is willing and capable of enforcing human rights. Both factors aggravate the Rana Plaza victims' struggles for compensation, due to insufficient Bangladeshi law, and the lack of binding responsibility of North American and European retailers along the supply chain. Companies acting flexibly on a global scale can deploy gaps that result from different levels of implementation and enforcement of human rights in different states. Low standards of human rights are not just a matter of weak states, but they represent a competitive advantage that attracts foreign direct investment.

The human rights regime increasingly begins taking the agency of business actors into account. Discussions of criminal liability (Kamminga and Zia-Zarifi 2000), extraterritoriality (Augenstein and Kinley 2013; Skogly 2013), investment arbitration (Steininger 2018), regulation (Vogel 2009), and multi-level litigation (Noortmann et al. 2015; Schrempf-Stirling and Wettstein 2017; Clapham 2006) are on the rise. Nevertheless, the question of business responsibility for human rights remains a highly disputed matter as it challenges a key component of international law: the distinction between public and private. ${ }^{4}$ This is visible in two main controversies.

\section{Controversy 1: Direct or indirect responsibility for human rights?}

In response to the gap between non-state business agency and state-centred human rights, the human rights regime offers two ideal-typical responses.

The first response characterises business as private actors, and aims at strengthening the indirect state responsibility for private actors. Yet, this response does not cover the gaps resulting from transnational business agency, and it relies on strong, capable, and committed states, the lack of which contributes to blatant gaps in the human rights regime in the first place. 
The second response addresses business companies directly, i.e. not via the state. Yet this response, too, causes controversies. In terms of international law, it begs the question whether it needs to treat business actors as subjects of international law (Clapham 2006; Nowak and Januszewski 2015), and if it simply equalises business responsibilities with state duties for human rights. In terms of political science, it begs the question whether an accompanying rise of power and legitimacy of business actors is feasible or whether it is desirable - and if so, in which forms (Goodhart 2006; Kamminga and Zia-Zarifi 2000). Some even fear a privatisation of human rights that would relieve the state of its duties and transfer human rights responsibilities to a privatised sphere (Hamm 2016; Rosemann 2005; McBeth 2004, but cf. Mende 2020a).

Ultimately, both responses struggle in developing a sufficient basis for business responsibility for human rights that can deal with current challenges and transformations. Apparently, it does not suffice to address business as only indirectly responsible private actors, nor to treat them as directly responsible public actors equal to states.

\section{Controversy 2: Soft law or hard law?}

The human rights regime knows further possibilities for dealing with private actors beyond state control. The lack of enforcement mechanisms on a global scale has always relied on alternative strategies to bolster human rights. One of these strategies is to make human rights violations public, and to pressure the relevant actors on moral terms: the strategy of naming and shaming. The human rights regime therefore contains two, mutually reinforcing dimensions: the juridical dimension (hard law) and the moral or normative dimension (soft law) (cf. Mende 2016, 168-74). The latter includes normative expectations as well as non-binding documents and standards.

Soft law plays a major role when it comes to business responsibilities for human rights. Business actors are regularly addressed publicly and pressured on moral terms. The employment of such strategies by civil society organisations during the 1990s has tremendously contributed to the development of the business and human rights agenda (Rowe 2005, 122-4; Grant and Keohane 2005, 35; Morrison 2011). It resulted in the establishment of codes of conduct, platforms for corporate performance (e.g. the United Nations (UN) Global Compact), stewardship commitments and global guidelines (e.g. the UN Guiding Principles on Business and Human Rights, or the Organisation for Economic Co-operation and Development Guidelines for Multinational Enterprises). These in turn provide an important basis for the moral dimension to work. Yet they often entail only weak mechanisms to enforce com- 
pliance from companies. Accordingly controversy arises, whether soft law contributes to an enhancement of the human rights regime or whether it is a mere window dressing that prevents hard law (cf. Addo 1999; Crane 2008; Deva and Bilchitz 2013).

The conflict between soft law and hard law, i.e. between binding and non-binding standards, for business goes back to the 1970s when the concept of corporate social responsibility (CSR) gained prominence. Since then, a visible rise of CSR can be witnessed, e.g. in corporate and accounting reports (KPMG International 2013, 13), whole sections of corporate reports and business plans dedicated to different forms of CSR (Dillard and Murray 2013), complaint mechanisms within corporate structures, CSR-related codes of conduct and platforms, the EU directive 2014/95, and the ISO norm 26000. The discourse on CSR challenged the shareholder model that saw business actors just accountable to their shareholders, in favour of a stakeholder model that strives to hold business actors responsible for activities that affect other parts of the population and the society in general. Yet, in spite of CSR's pluralist usages, it is commonly understood as a voluntary instrument. As such it is criticised as undermining human rights and as ineffective; others welcome CSR as a step towards more comprehensive forms of corporate responsibility; and yet others see it as an effective instrument to circumvent binding regulation (Conzelmann and Wolf 2008; Crane et al. 2008; Gond and Moon 2012; Rowe 2005).

Ultimately, the debates are marked by the key question whether business actors should be seen as mere private actors or as public actors with public responsibilities (Scherer and Palazzo 2008, 419ff.; Levy and Kaplan 2008, 434; Kobrin 2009). This is because non-binding standards easily apply to private actors, while binding standards challenge their private role.

\section{A threefold approach: the public, the private, and the business-societal}

Both controversies address the possibilities and limits to hold business companies responsible for human rights. Both are structured by the underlying conflict between public and private. At the same time, both demonstrate that one-dimensional solutions choosing only one of the two sides do not suffice. Thus they show the insufficiency of a dichotomous separation between public and private - or, in terms of international law, between state and non-state roles. 
The developments in the fields of global governance and human rights indicate emerging roles of business companies that move beyond the classic two-pole constellation between public and private. Rather, they are developing a hybrid role. Recent discussions increasingly address these hybrid roles of companies, e.g. in concepts of political CSR (Scherer et al. 2016; Scherer and Palazzo 2007), global CSR (Stohl et al. 2007), democratic CSR (Levy and Kaplan 2008, 439ff.), extended corporate citizenship (Crane et al. 2008), corporations as next to governments (Wettstein 2009; Ciepley 2013), private government (Anderson 2017), or the political power and authority of companies (Fuchs 2013, 87; Atal 2019). These concepts differ with regard to the specific roles and features of companies, and their position in the constellation between public and private. They agree that companies have more agency and power than private actors, but that they differ from state actors. Companies are in between. But what does that mean exactly?

\section{Not just private}

On the one hand, companies are not just private actors: "business firms have started to engage in activities that have traditionally been regarded as actual governmental activities" (Scherer and Palazzo 2011, 899). Business companies assume issues and tasks that states have been responsible for. These tasks are closely associated with the common good, which is why they have been linked to states as public actors in the first place (Abrahamsen and Williams 2014, 244ff.; Reus-Smit 2001, 530ff.). This privatisation concerns public services and infrastructure, including education, health, the supply of water, electricity, gas, or the management of prisons and hospitals (Leibfried and Zürn 2005; Graz and Nölke 2008), and even matters of peace, conflict, and security (Deitelhoff and Wolf 2010; Flohr et al. 2010). This entails a shift of authority and responsibility to companies - not necessarily against or beyond the state, but also in cooperation and coexistence with states (Moon and Knudsen 2018; Atal 2019, cf. Oberleitner/Starl and Forsythe in this volume).

Striking examples are corporate villages both in the Global South and the Global North. Those are residential areas in which companies provide employees and their families with a variety of public services such as schools or hospitals. Besides their supportive effects, they implement a high degree of dependency and political authority of the company. For example, Amazon and Apple are currently establishing healthcare facilities and clinics for their employees in the United States, in order to fill gaps in the public healthcare system and to attract high-skilled employees. Del Monte Kenya implemented clinics and an award-winning HIV/AIDS prevention programme for its employees in several Kenyan communities, significantly reducing the spread rate. However, the 
programme is also accompanied by far-reaching measures. Workers are called to report suspicious disease symptoms from their neighbours to the company clinics (Atal 2019, 162ff.). Generally, "when corporations take on these governing roles, they gain the authority to decide what form of governance to provide: what subjects are taught in schools, what diseases are excluded from health care services and what family structures are permitted in company housing policy, for example. In doing so, they are making moral judgments about how people should behave and how society should be organised" (Atal 2019, 10).

Furthermore, business companies are participating in global governance mechanisms which are generally marked by an aspiration to contribute to the common good (Mende 2020b). They participate in the development, setting, and interpretation of norms and standards for themselves and for others, and they monitor the implementation of international treaties (Green 2010; Kocher 2009; Peters et al. 2009; Muchlinski 2010).

Taken together, business activities are not only marked by a rise of agency, authority, and power. They are also closely tied to public, social, and moral questions. Their activities yield far-reaching effects on a wide range of proximate and remote stakeholders (cf. Winkler in this volume), situating companies far beyond the private sphere.

\section{Not just public}

On the other hand, business actors are not simply public actors. "The fact is, no matter how appealing it may be as a political and intellectual construct, organizations are not societies in the political sense, and managements are not governments" (Kerr 2004). Companies are not endowed with judicative, legislative, and executive powers; neither do they necessarily have institutionalised mechanisms for checks and balances of power (Crane et al. 2008, 92). In spite of the power and agency of companies, there is a profound difference between companies and states. This difference is highly important: companies do not entail mechanisms of democratic elections or accountability. While they yield influence in international organisations and multilateral agreements, they do not have the same voice and official standing as states do. Finally, they do not have the same duties as states do.

For example, Lonmin Mining installed public services such as street lights and sewer systems in communities in the South African platinum belt. Yet Lonmin Mining did not provide for their maintenance. Since the assets were not properly transferred to the municipality either, they decayed unattended (Bench Marks Foundation and Rustenburg Community Groups 2011, 41f.). 
Similarly, when workers lose their jobs in a corporate village, or the company closes its asset altogether, the people left behind lose access to the services too, including schools, housing, and clinics that were provided by the company only on a voluntary and temporary basis.

This is because business companies have private rights, private properties, and a legitimated private interest (e.g. in pursuing profit). While business activities are closely tied to the public good, the latter is not their genuine purpose.

\section{Business-societal as a third pole}

Taken together, the role of business companies cannot be properly captured with the classic notions of public and private. Rather, they are situated between and beyond. Companies provide public services and reach into the private spheres of stakeholders, yet without corresponding democratic mechanisms and insufficient duties or balances of power. They pursue private interests, yet they try (or are asked to) reconcile them with public interests. State-owned enterprises represent an even more striking example for the blurring between private and public roles.

Still it does not suffice to settle for a notion of a "blurring" between public and private (Mikler 2013a, 7), or a "messy public/private offshoot" (Ciepley 2013, 141). Rather, the argument needs further distinction with regard to the specific roles of companies as well as their relations and (dis)connections to the public and the private. Only then does it provide the basis for a viable discussion of correspondingly hybrid human rights responsibilities.

Therefore this chapter argues for a threefold approach. It proposes the concept of the business-societal, situated in an intermediated three-pole constellation with the public and the private.

In a first step, I suggest an analytical model of mediation between public and private that acknowledges their interdependence and mutual constitution (Mende 2020a). Public and private mutually constitute each other, and none would exist without the other. They are externally mediated in that each sphere's inclusion is the other sphere's exclusion and vice versa. They are internally mediated in that each sphere touches the scope, logics, and content of the other sphere, by means of regulation, deregulation, or non-intervention. Rather than considering one sphere as residual of the other, each sphere has specific functions for and effects on the other sphere, while they remain distinctive at the same time. This constellation captures how a phenomenon in one sphere is constituted and shaped by processes in the other sphere. A case 
in point is the family. Being at the heart of virtually every definition of the private, ${ }^{5}$ the power relations and gender constellations within the family are not simply happening outside the public, but they are framed and constituted by family policies, divorce law, access to public resources, etc. ${ }^{6}$

In a second step, I suggest to extend the intermediated two-pole constellation between public and private towards a three-pole constellation between public, private, and the business-societal. In this constellation, the societal roles of companies build a third pole beyond the public and the private (cf. Figure 11.1).

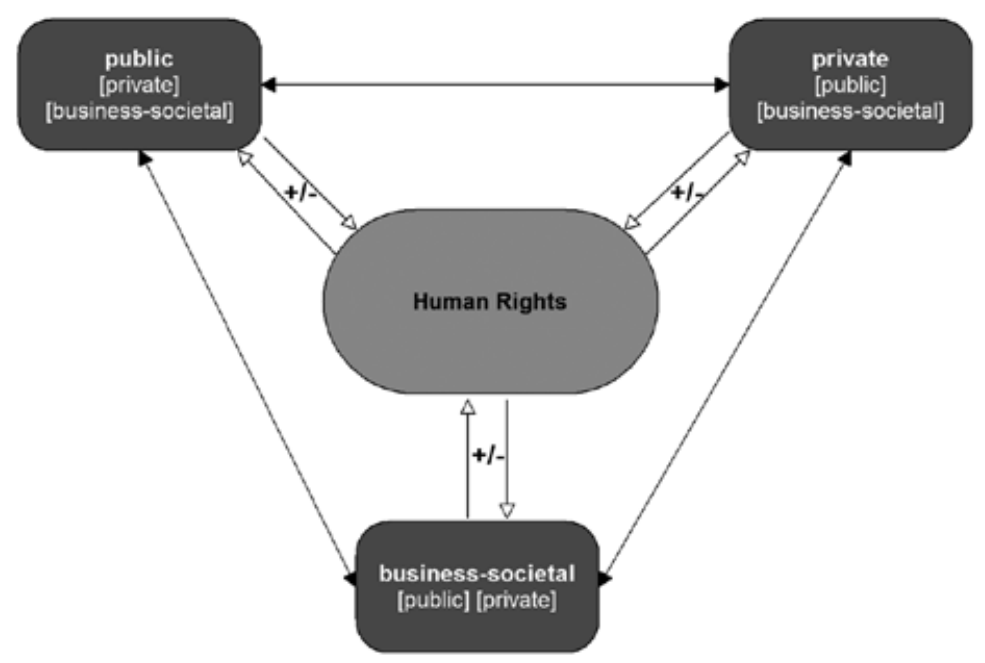

Figure 11.1 Three-pole constellation between the public, the private, and the business-societal

In analytical terms, each pole is intermediated with each of the two other poles. It has effects on each other pole, and it is affected by each other pole (cf. the square brackets, and the arrows between the poles in Figure 11.1). While being interdependent, the poles do not just dissolve or blur into each other. Rather they remain distinct, with distinct features, roles, and effects on human rights.

The human rights regime is affected by the three-pole constellation in different ways. This means that the societal roles of business companies do not simply harm or strengthen human rights. Rather, each role may have both emancipa- 
tory and repressive effects on human rights, sometimes even simultaneously (cf. the plus and minus signs in Figure 11.1).

In substantial terms, the meanings of public and private follow international law and its distinction between state and non-state actors. At the same time, they are open to contestation and contingence. The term "business-societal" entails the acknowledgement of other societal actors that move beyond the public and the private. Most strikingly, civil society actors may deploy similarly hybrid functions (cf. Tallberg et al. 2015; Jönsson and Tallberg 2010). ${ }^{7}$ Thus, the third pole of the societal can contain different actors, while here the term business-societal puts emphasis on the societal roles of business actors.

Furthermore, the constellation is about roles of actors. That means it is neither about the economy or the market as a depersonalised sphere; nor is it about statically categorising an actor in only one way. Rather, it is about identifying the different roles that actors can take on, simultaneously or at different times.

Ultimately, the three-pole approach is a conceptual model that analytically separates what might overlap empirically. The point is that even with regard to the overlap of empirical phenomena, or with the concurrency of different roles, a two-pole constellation does not capture the genuinely hybrid roles of business actors between and beyond the public and the private.

\section{Research agenda: business-societal responsibility for human rights}

The societal role of companies is a current and future research agenda for human rights, as it provides the basis for developing corresponding societal forms of business responsibility for human rights. As shown above, a great deal of debates and conflicts in the area of business and human rights arise from the juxtaposition of public and private roles. Correspondingly, there is a juxtaposition of binding state responsibilities for the respect, protection, and fulfilment for human rights, on the one hand, and non-binding or passive business responsibilities for the respect of human rights, on the other hand. ${ }^{8}$ In contrast, the hybrid business-societal allows developing correspondingly hybrid forms of business-societal responsibilities.

The threefold approach provides a basis for developing societal forms of business responsibility in tracing the interdependencies and effects of business roles on the public, the private, and the human rights regime (cf. the multi- 
ple occurrences of the "business-societal" in Figure 11.1). It shows that, for example, the family at the very core of the private is not only influenced and shaped by the public, as discussed above. It is also business activities in terms of wage level, wage distribution, hiring, or promoting that have profound effects on (power) relations within the private sphere of the family (Prügl and True 2014; Meyersfeld 2013). Furthermore, representations of gender, ethnic, or other collective identities in advertisements, marketing, entertainment, or the media influence the (self-)perception of those very identities within the private sphere in various ways (Hall 1992). A recently launched campaign called "Unstereotype Alliance" shows that companies and civil society are aware of this interdependence. The platform founded by transnational companies, convened by United Nations Women, "seeks to eradicate harmful gender-based stereotypes" in advertisements. ${ }^{9}$

Similarly, business affects the public sphere. The agency, the power, and also the legitimacy of states are affected by the ways they deal, cooperate, or govern with companies. The structures and mechanisms of international organisations, too, are challenged by the increasingly crucial role that business actors (as well as other non-state actors such as non-governmental organisations) are playing for processes and fora of global deliberation and global governance. Furthermore, notions of the common good are affected by shifting their provision towards business actors.

The threefold approach also captures the effects on business companies themselves. New responsibilities, regulatory entitlements, demands for and access to legitimacy influence internal "organizational responses, structures and identities" of companies, as well as "their interactions with competitors in their peer groups and with other governance actors" (Scherer et al. 2016, 287). A case in point is Danone's and Blackrock chief executive officer Larry Fink's proposals to produce value-based contributions, or the different generations of CSR (Stohl et al. 2007).

Ultimately, the threefold approach recognises that business activities and their effects on human rights do not simply occur beyond or without the state. Rather, they are closely connected and interdependent in various ways. Therefore, business-societal responsibilities can contribute to a human rights regime in which different actors' responsibilities supplement and complement each other, instead of simply substituting state duties, or transferring responsibilities to private, non-transparent spheres, out of sight and reach of the public and of civil society. ${ }^{10}$ 
If developed carefully and examined critically, societal business responsibility for human rights can strengthen the respect, protection, and fulfilment of human rights. It is the task of the hereby proposed research agenda to discuss such societal forms of business responsibility for human rights, and to examine their repercussions as well as their productive effects.

\section{Notes}

1. This chapter is based on research that is funded by the Deutsche Forschungsgemeinschaft (German Research Foundation), project number 398306144.

2. www.business-humanrights.org/en/work-injury-compensation-still-missing-in -bangladesh\%E2\%80\%99s-labour-standards. Last access: 3 March 2019.

3. The hybrid roles of companies have historical predecessors, yet this chapter focuses on the peculiar constellation of globalisation and global governance, and on the modern human rights system that has only been established since 1945 .

4. The public character of international law and its foundation on a binary between a public (state-centred) and private sphere has been criticised even before the rise of global governance. Feminist perspectives have stressed that human rights violations of women usually occur in the private sphere of the household (Charlesworth et al. 1991; Chinkin 1999; Mackinnon 1991; Peters and Wolper 1995). While this led to an inclusion of the private household into the realm of women's human rights, the responsibility for the respect, protection, and fulfilment of human rights remains with the state.

5. Definitions of public and private are pluralist due to different schools of thought, on the one hand, and due to political and social struggles and contingence, on the other hand.

6. Against this background, Ciepley's political theory of the company falls short, when he states that "unlike private bodies, such as families and voluntary associations, corporations cannot be formed without civil government" $(2013,140)$. The underlying dichotomous assumption does not suffice to capture the interdependence between public and private in the first place.

7. Civil society organisations have largely contributed to the development of the business and human rights agenda in the first place (Vogel 2009).

8. A case in point are the so-called United Nations Draft Norms that failed to install binding human rights obligations for business companies in 2003. They were criticised for putting companies and states on the same level (Ruggie 2017).

9. www.unstereotypealliance.org. Last access: 25 October 2018.

10. Current developments like the United Nations Guiding Principles are already paving the way for such interdependent responsibility networks (cf. Mende 2018). 


\section{References}

Abrahamsen, Rita, and Michael C. Williams. 2014. "Publics, Practices and Power." In The Return of the Public in Global Governance, edited by Jacqueline Best and Alexandra Gheciu, 243-56. Cambridge: Cambridge University Press.

Addo, Michael K., ed. 1999. Human Rights Standards and the Responsibility of Transnational Corporations. The Hague: Kluwer.

Anderson, Elizabeth. 2017. Private Government: How Employers Rule Our Lives (and Why We Don't Talk about It). Princeton, NJ; Ann Arbor, MI: Princeton University Press; ProQuest.

Atal, Maha Rafi. 2019. When Companies Rule: Corporate Political Authority in India, Kenya and South Africa. Cambridge: Apollo - University of Cambridge Repository.

Augenstein, Daniel, and David Kinley. 2013. "When Human Rights 'Responsibilities' Become 'Duties': The Extra-Territorial Obligations of States that Bind Corporations." In Deva and Bilchitz 2013, 271-94.

Barrientos, Stephanie. 2007. Global Production Systems and Decent Work. Working paper 77. Geneva: International Labour Organization.

Bench Marks Foundation and Rustenburg Community Groups. 2011. Rustenburg Community Report 2011. Johannesburg: Bench Marks Foundation.

Brühl, Tanja, and Volker Rittberger. 2001. "From International to Global Governance: Actors, Collective Decision-Making, and the United Nations in the World of the Twenty-First Century." In Global Governance and the United Nations System, edited by Volker Rittberger, 1-47. Tokyo, New York: United Nations University Press.

Brysk, Alison, ed. 2002. Globalization and Human Rights. Berkeley, CA: University of California Press.

Charlesworth, Hilary, Christine Chinkin, and Shelley Wright. 1991. "Feminist Approaches to International Law." American Journal of International Law 85 (4): 613-45.

Chinkin, Christine. 1999. "A Critique of the Public/Private Dimension." European Journal of International Law 10 (2): 387-95.

Ciepley, David. 2013. "Beyond Public and Private: Toward a Political Theory of the Corporation.” American Political Science Review 107 (1): 139-58. https://doi.org/10 $.1017 /$ S0003055412000536.

Clapham, Andrew. 2006. Human Rights Obligations of Non-State Actors. Oxford: Oxford University Press.

Conzelmann, Thomas, and Klaus Dieter Wolf. 2008. "The Potential and Limits of Governance by Private Codes of Conduct." In Transnational Private Governance and Its Limits, edited by Jean-Christophe Graz and Andreas Nölke, 98-114. London: Routledge.

Crane, Andrew, ed. 2008. The Oxford Handbook of Corporate Social Responsibility. Oxford: Oxford University Press.

Crane, Andrew, Dirk Matten, and Jeremy Moon. 2008. Corporations and Citizenship: Business, Value Creation, and Society. Cambridge: Cambridge University Press.

Deitelhoff, Nicole, and Klaus Dieter Wolf, eds. 2010. Corporate Security Responsibility? Corporate Governance Contributions to Peace and Security in Zones of Conflict. Basingstoke: Palgrave Macmillan.

Deva, Surya, and David Bilchitz, eds. 2013. Human Rights Obligations of Business: Beyond the Corporate Responsibility to Respect? Cambridge: Cambridge University Press. 
Dicken, Peter. 2011. Global Shift, Sixth Edition: Mapping the Changing Contours of the World Economy. New York: Guilford Press. http://gbv.eblib.com/patron/FullRecord .aspx? $\mathrm{p}=593767$.

Dillard, Jesse, and Alan Murray. 2013. "Deciphering the Domain of Corporate Social Responsibility." In Corporate Social Responsibility: A Research Handbook, edited by Kathryn Haynes, Alan Murray, and Jesse Dillard, 10-27. Abingdon: Routledge.

Flohr, Annegret, Lothar Rieth, Sandra Schwindenhammer, and Klaus Dieter Wolf. 2010. The Role of Business in Global Governance: Corporations as Norm-Entrepreneurs. Basingstoke: Palgrave Macmillan.

Fuchs, Doris. 2005. Understanding Business Power in Global Governance, 1st ed. Baden-Baden: Nomos.

Fuchs, Doris. 2013. “Theorizing the Power of Global Companies.” In Mikler 2013b, 77-95.

Gond, Jean-Pascal, and Jeremy Moon, eds. 2012. Corporate Social Responsibility, Volume 1. London: Routledge.

Goodhart, Michael. 2006. "Human Rights and Non-State Actors: Theoretical Puzzles." In Non-State Actors in the Human Rights Universe, edited by George J. Andreopoulos, Zehra F. K. Arat, and Peter H. Juviler, 23-42. Bloomfield, IN: Kumarian Press.

Grant, Ruth W., and Robert O. Keohane. 2005. "Accountability and Abuses of Power in World Politics.” American Political Science Review 99 (1): 29-43. https://doi.org/10 .1017/S0003055405051476.

Graz, Jean-Christophe, and Andreas Nölke, eds. 2008. Transnational Private Governance and Its Limits. London: Routledge.

Green, Jessica F. 2010. "Private Authority on the Rise: A Century of Delegation in Multilateral Environmental Agreements." In Transnational Actors in Global Governance: Patterns, Explanations, and Implications, edited by Christer Jönsson and Jonas Tallberg, 155-76. Basingstoke: Palgrave Macmillan.

Hall, Stuart. 1992. "The Question of Cultural Identity." In Modernity and Its Futures, edited by Stuart Hall, David Held, and Anthony McGrew, 273-316. Cambridge: Polity Press.

Hamm, Brigitte. 2016. "Die UN-Leitprinzipien für Wirtschaft und Menschenrechte: Auswirkungen auf das Menschenrechtsregime.” KJ 49 (4): 479-95. https://doi.org/ 10.5771/0023-4834-2016-4-479.

Jönsson, Christer, and Jonas Tallberg, eds. 2010. Transnational Actors in Global Governance: Patterns, Explanations, and Implications. Basingstoke: Palgrave Macmillan.

Kamminga, Menno T., and Saman Zia-Zarifi, eds. 2000. Liability of Multinational Corporations under International Law. The Hague: Kluwer Law International.

Kerr, Jeffrey L. 2004. "The Limits of Organizational Democracy.” AMP 18 (3): 81-95. https://doi.org/10.5465/ame.2004.14776172.

Kobrin, Stephen J. 2009. "Private Political Authority and Public Responsibility: Transnational Politics, Transnational Firms, and Human Rights.” Business Ethics Quarterly 19 (3): 349-74. https://doi.org/10.5840/beq200919321.

Kocher, Eva. 2009. "Private Standards in the North: Effective Norms for the South?" In Non-State Actors as Standard Setters, edited by Anne Peters, Lucy Koechlin, Till Förster, and Gretta F. Zinkernagel, 409-30. Cambridge: Cambridge University Press.

KPMG International. 2013. The KPMG Survey of Corporate Social Responsibility Reporting 2013. KPMG International.

Leibfried, Stephan, and Michael Zürn, eds. 2005. Transformations of the State? Cambridge: Cambridge University Press. 
Levy, David L., and Rami Kaplan. 2008. "Corporate Social Responsibility and Theories of Global Governance: Strategic Contestation in Global Issue Arenas." In Crane 2008, 432-51.

Mackinnon, Catharine A. 1991. Toward a Feminist Theory of the State. Cambridge, MA: Harvard University Press.

McBeth, Adam. 2004. "Privatising Human Rights: What Happens to the State's Human Rights Duties When Services Are Privatised?” Melbourne Journal of International Law 5 (1).

Mende, Janne. 2016. A Human Right to Culture and Identity? The Ambivalence of Group Rights. London: Rowman and Littlefield International.

Mende, Janne. 2017. "Privatisierung oder Diffusion von Verantwortung? Die Entwicklung wirtschaftlicher Verantwortung für Menschenrechte." In Politische Vierteljahresschrift. Sonderheft 52: Politik und Verantwortung, edited by Christopher Daase, Julian Junk, Stefan Kroll, Valentin Rauer, 409-35. Baden-Baden: Nomos.

Mende, Janne. 2018. "The United Nations Guiding Principles on Business and Human Rights (2011)." In Sources of the History of Human Rights, edited by the Study Group Human Rights in the 20th Century (Fritz Thyssen Foundation). www.geschichte -menschenrechte.de/business-human-rights/.

Mende, Janne. 2020a. "Business Authority in Global Governance: Beyond Public and Private.” WZB Berlin Social Science Center Discussion Paper 2020 (103). https:// bibliothek.wzb.eu/pdf/2020/iv20-103.pdf.

Mende, Janne. 2020b. "Global Governance." In The Palgrave Encyclopedia of Global Security Studies, edited by Scott Romaniuk, Peter Marton, and Manish Thapa. Cham: Palgrave Macmillan. https://link.springer.com/referenceworkentry/10.1007/ 978-3-319-74336-3_220-1.

Meyersfeld, Bonita. 2013. "Business, Human Rights and Gender: A Legal Approach to External and Internal Considerations." In Deva and Bilchitz 2013, 193-217.

Mikler, John. 2013a. "Global Companies as Actors in Global Policy and Governance." In Mikler 2013b, 1-15.

Mikler, John, ed. 2013b. The Handbook of Global Companies. Chichester: Wiley-Blackwell.

Moon, Jeremy, and Jette Steen Knudsen. 2018. "Corporate Social Responsibility and Government.” Proceedings 2018 (1): 12777. https://doi.org/10.5465/AMBPP.2018 .12777abstract.

Morrison, John. 2011. "An Overview of Current Practice and Policy Relating to Business Activities and Human Rights: Some of the Implications for Corporate 'Rule-Making'”. In Corporate Citizenship and New Governance: The Political Role of Corporations, edited by Ingo Pies and Peter Koslowski, 7-18. Berlin: Springer.

Muchlinski, Peter. 2001. "Human Rights and Multinationals: Is There a Problem?" International Affairs 77 (1): 31-48. https://doi.org/10.1111/1468-2346.00176.

Muchlinski, Peter. 2010. "Multinational Enterprises as Actors in International Law: Creating 'soft Law' Obligations and 'Hard Law' Rights.” In Non-State Actor Dynamics in International Law: From Law-Takers to Law-Makers, edited by Math Noortmann and Cedric Ryngaert, 9-40. Farnham: Ashgate.

Noortmann, Math, August Reinisch, and Cedric Ryngaert, eds. 2015. Non-State Actors in International Law. Oxford: Hart Publishing. https://books.google.at/books?id= 97I-CgAAQBAJ.

Nowak, Manfred, and Karolina Miriam Januszewski. 2015. "Non-State Actors and Human Rights." In Non-State Actors in International Law, edited by Math Noortmann, August Reinisch, and Cedric Ryngaert, 113-62. Oxford: Hart Publishing. 
Peters, Anne, Lucy Koechlin, Till Förster, and Gretta Fenner Zinkernagel, eds. 2009. Non-State Actors as Standard Setters. Cambridge: Cambridge University Press.

Peters, Julie, and Andrea Wolper, eds. 1995. Women's Rights, Human Rights: International Feminist Perspectives. New York: Routledge.

Prügl, Elisabeth, and Jacqui True. 2014. "Equality Means Business? Governing Gender through Transnational Public-Private Partnerships." Review of International Political Economy 21 (6): 1137-69. https://doi.org/10.1080/09692290.2013.849277.

Reus-Smit, Christian. 2001. "Human Rights and the Social Construction of Sovereignty." Review of International Studies 27 (4): 519-38.

Rosemann, Nils. 2005. "The Privatization of Human Rights Violations: Business' Impunity or Corporate Responsibility? The Case of Human Rights Abuses and Torture in Iraq." Non-State Actors and International Law 5 (1): 77-100. https://doi .org/10.1163/1571807054068198.

Rosenau, James N., and Ernst Otto Czempiel, eds. 1992. Governance without Government: Order and Change in World Politics. Cambridge, New York: Cambridge University Press.

Rowe, James K. 2005. “Corporate Social Responsibility as Business Strategy.” In Globalization, Governmentality and Global Politics: Regulation for the Rest of Us? edited by Ronnie D. Lipschutz and James K. Rowe, 122-60. London: Routledge.

Ruggie, John G. 2017. "The Social Construction of the UN Guiding Principles on Business and Human Rights." Corporate Responsibility Initiative Working Paper 67.

Sassen, Saskia. 2006. Territory, Authority, Rights: From Medieval to Global Assemblages. Princeton, NJ: Princeton University Press. http://lib.myilibrary.com/detail.asp?id= 215885.

Scherer, Andreas Georg, and Guido Palazzo. 2007. “Toward a Political Conception of Corporate Responsibility: Business and Society Seen from a Habermasian Perspective." Academy of Management Review 32 (4): 1096-120. https://doi.org/10 .5465/AMR.2007.26585837.

Scherer, Andreas Georg, and Guido Palazzo. 2008. "Globalization and Corporate Social Responsibility." In Crane 2008, 413-31.

Scherer, Andreas Georg, and Guido Palazzo. 2011. "The New Political Role of Business in a Globalized World: A Review of a New Perspective on CSR and Its Implications for the Firm, Governance, and Democracy." Journal of Management Studies 48 (4): 899-931. https://doi.org/10.1111/j.1467-6486.2010.00950.x.

Scherer, Andreas Georg, Andreas Rasche, Guido Palazzo, and André Spicer. 2016. "Managing for Political Corporate Social Responsibility: New Challenges and Directions for PCSR 2.0." Journal of Management Studies 53 (3): 273-98. https://doi .org/10.1111/joms.12203.

Schrempf-Stirling, Judith, and Florian Wettstein. 2017. "Beyond Guilty Verdicts: Human Rights Litigation and Its Impact on Corporations' Human Rights Policies." Journal of Business Ethics 145 (3): 545-62. https://doi.org/10.1007/s10551-015-2889 $-5$.

Schuppert, Gunnar Folke, ed. 2006. Global Governance and the Role of Non-State Actors, 1st ed. Baden-Baden: Nomos.

Skogly, Sigrun. 2013. "Causality and Extra-Territorial Human Rights Obligations." In Global Justice, State Duties: The Extraterritorial Scope of Economic, Social, and Cultural Rights in International Law, edited by Malcolm Langford, Wouter Vandenhole, Martin Scheinin, and Willem van Genugten, 233-58. New York: Cambridge University Press. 
Steininger, Silvia. 2018. "What's Human Rights Got to Do with It? An Empirical Analysis of Human Rights References in Investment Arbitration." Leiden Journal of International Law 31 (1): 33-58. https://doi.org/10.1017/S0922156517000528.

Stohl, Michael, Cynthia Stohl, and Nikki C. Townsley. 2007. "A New Generation of Global Corporate Social Responsibility." In The Debate over Corporate Social Responsibility, edited by Steve May, George Cheney, and Juliet Roper, 30-44. Oxford: Oxford University Press.

Take, Ingo, ed. 2009. Legitimes Regieren jenseits des Nationalstaates: Unterschiedliche Formen von Global Governance im Vergleich, 1st ed. Baden-Baden: Nomos.

Tallberg, Jonas, Lisa M. Dellmuth, Hans Agné, and Andreas Duit. 2015. "NGO Influence in International Organizations: Information, Access and Exchange." British Journal of Political Science, 1-26. https://doi.org/10.1017/S000712341500037X.

UNCTAD. 2015. World Investment Report 2015: Reforming International Investment Governance. New York, Geneva: United Nations.

Vogel, David. 2009. "The Private Regulation of Global Corporate Conduct." In The Politics of Global Regulation, edited by Walter Mattli and Ngaire Woods, 151-88. Princeton, NJ: Princeton University Press.

Wettstein, Florian. 2009. Multinational Corporations and Global Justice: The Human Rights Obligations of a Quasi-Governmental Institution. Stanford, CA: Stanford Business Books. 
Janne Mende - 9781788973083 Downloaded from PubFactory at 04/26/2023 10:04:58AM via free access 